\title{
Two new black mildews from Mahabaleshwar, Maharashtra, India
}

\section{B. Hosagoudar*, P. J. Robin and G. R. Archana}

Tropical Botanic Garden and Research Institute, Palode 695 562, Thiruvananthapuram (Kerala), INDIA

*Corresponding author. E-mail: vbhosagoudar@rediffmail.com

Abstract: This paper gives an account of two new black mildews, namely, Asterina prataparaiii and Meliola mahamulkarii, infected the leaves of Tylophora dalzelliand Osyris arborea, respectively, were found new and are described and illustrated here in detail.

Keywords: Black mildews, Asterina, Meliola, New species, Mahabaleshwar

\section{INTRODUCTION}

Melcolm Peth, Nahar or Mahabaleshwar, a holy abode of Lord Shiva, termed as "Mild Paradise of Beauty", is located in Satara district of Maharashtra, at $17^{\circ} 51^{\prime}$ NL and $73^{\circ} 30^{\prime} \mathrm{EL}$, spreads to $150 \mathrm{sq} \mathrm{km}$, at altitude of 4500 $\mathrm{ft}$. with highest Wilson point of $4710 \mathrm{ft}$., having rainfall ranging from 107 to 402 inches, temperature from 17 to $26^{\circ} \mathrm{C}$. This place harbours 'hill top shola or montane forest" and an account of the flowering plants and its adjoining area was dealt by Deshpande et al. (1993). Several attempts have been made to study the fungi of this region (Patil and Thite, 1980-81; Ursekar, 1977; Kamat et al., 1971; Srinivasulu, 1974) but a thorough survey and its systematic account of the fungal flora is awaited. As a part of the study of Asterinales of India, authors collected several foliicolous fungi in Kas Lake, Mahabaleshwar and nearby places in Satara district. Of these, only an account of two new black mildews is dealt herewith.

\section{Taxonomy}

Asterina prataprajii V.B. Hosagoudar, P.J. Robin and G.R. Archana, sp. nov. (Fig.1). Etymology: Named in honour of Dr. Pratapraj Chavan, teacher of the senior author (vbh).

Coloniae hypophyllae, subdensae, ad $3 \mathrm{~mm}$ diam., plerumque confluentes. Hyphae flexuosae, opposite vel alternatim acuteque ramosae, laxe vel arte reticulatae, cellulae 17-22 x 3-4 $\mu \mathrm{m}$. Appressoria numerosa, alternata, bi-cellula, antrorsa vel subantrosa, 12-16 $\mu \mathrm{m}$ longa; cellulae basilares cylindraceae, 3-10 $\mu \mathrm{m}$ longae; cellulae apicales globosae, lobatae, 6-10 x 8-10 $\mu \mathrm{m}$. Thyriothecia dispersa, saepe 1-2 connata, orbicularis, ad $108 \mu \mathrm{m}$ diam.; margine crenatae vel fimbriatae, stellatim dehiscentes ad center; asci numerosi, globosi, octospori, 31-38 $\mu$ m diam.; ascosporae conglobatae, brunneae, 1-septatae, fortiter constrictus ad septatae, $14-19 \times 10-12 \mu \mathrm{m}$, parietus glabrus.
Colonies hypophyllus, subdense, up to $3 \mathrm{~mm}$ in diameter, mostly confluent. Hyphae flexuous, branching opposite to alternate at acute angles, loosely to closely reticulate, cells 17-22 x 3-4 $\mu \mathrm{m}$. Appressoria numerous, alternate, 2celled, antrorse to subantrorse, 12-16 $\mu \mathrm{m}$ long; stalk cells cylindrical, 3-10 $\mu \mathrm{m}$ long; head cells ovate, globose, lobate, 6-10 x 8-10 $\mu \mathrm{m}$. Thyriothecia scattered, often 1-2 connate, orbicular, up to $108 \mu \mathrm{m}$ in diameter; margin crenate to fimbriate, dehisce stellately at the center; asci many, globose, octosporous, 31-38 $\mu \mathrm{m}$ in diameter; ascospores conglobate, brown, 1-septate, deeply constricted at the septum, 14-19 x 10-12 $\mu \mathrm{m}$, wall smooth.

Materials examined: On leaves of Tylophora dalzelli (Burm.f.) Merr. (Asclepiadaceae), Mahabeleswar, Maharastra, Jan. 1, 2009, V.B. Hosagoudar and al TBGT 3689 (type).

There are eight species of the genus Asterina known on the members of the family Asclepiadaceae, namely Asterina asclepiadis Hosag. and Goos (Hosagoudar and Goos, 1996), A. concinna Sydow (Sydow, 1930), A. cynanchi Hosag. and Shiburaj (Hosagoudar, 2002), A. heterostemmae Yamam. (Yamamoto, 1956), A. leonensis Sydow (Sydow, 1938), A. peraffinis Speg. (Theissen, 1913), A. toxocarpi Hosag. and C.K. Biju (Hosagoudar, 2005), A. travencorensis Sydow and Sydow (Sydow and Sydow, 1915) and A. tylophorae-indicae Hosag. et al. (Hosagoudar et al. 2006). All these species having two celled appressoria except Asterina tylophorae-indicae. However, the present species differs from it in having typically lobate appressoria.

Meliola mahamulkarii V.B. Hosagoudar, P.J. Robin and G.R. Archana, sp. nov. (Fig. 2)

Etymology: Named in honour of Dr. S.H. Mahamulkar for his contributions to Meliolales

Coloniae amphigenae, plerumque epiphyllae, densae, ad $2 \mathrm{~mm}$ diam. Hyphae rectae vel subrectae, opposite acuteque ramosae, dense reticulatae, cellulae 24-31 x 5-7 


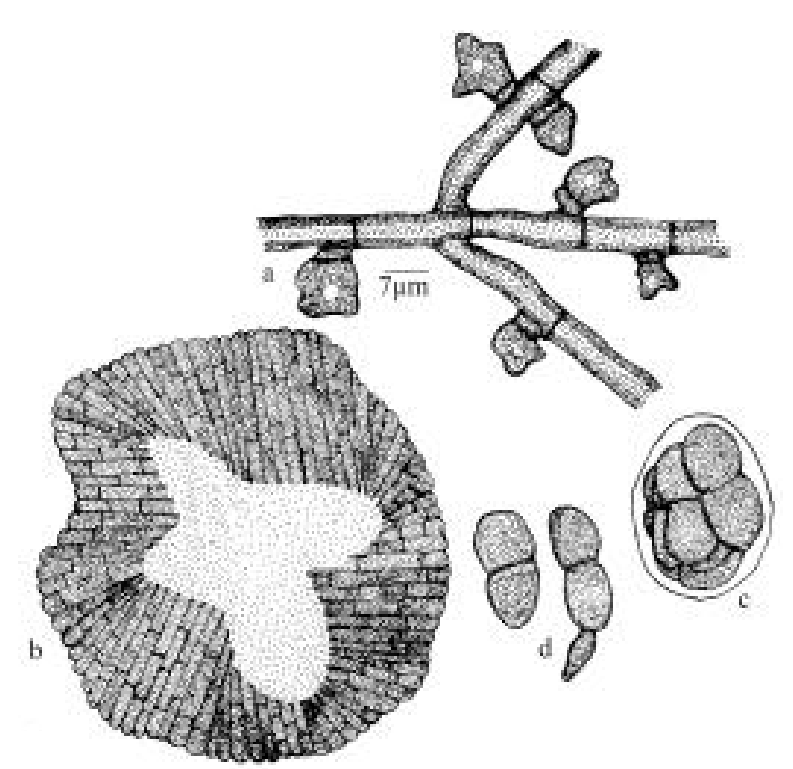

Fig. 1. Asterina prataprajii sp. nov. a. Appressoriate mycelium, $b$. Thyriothecium, c. Ascus, d. Ascospores.

$\mu \mathrm{m}$. Appressoria opposita vel alternata, antrorsa, 12-17 $\mu \mathrm{m}$ longa; cellulae basilares cylindraceae vel cuneatae, 2-5 $\mu \mathrm{m}$ longae; cellulae apicales ovatae vel globosae, integrae, 7-12 x 5-7 $\mu \mathrm{m}$. Phialides appressoriis mixtus, alternatae vel oppositae, ampulliformes, 14-19 x 7-10 $\mu \mathrm{m}$. Setae myceliales dispersae, rectae, simplices, obtusae ad apicem, ad $440 \mu \mathrm{m}$ longae. Perithecia dispersa, ad $178 \mu \mathrm{m}$ diam.; ascosporae obovoideae, 4-septatae, constrictus ad septatae, 43-50 x 17-19 $\mu \mathrm{m}$.

Colonies amphigenous, mostly epiphyllous, dense, up to $2 \mathrm{~mm}$ in diameter. Hyphae straight to substraight, branching opposite at acute angles, closely reticulate, cells 24-31 x 5-7 $\mu \mathrm{m}$. Appressoria opposite to alternate, antrorse, $12-17 \mu \mathrm{m}$ long; stalk cells cylindrical to cuneate, 2-5 $\mu \mathrm{m}$ long; head cells ovate to globose, entire, 7-12 x 5$7 \mu \mathrm{m}$. Phialides mixed with appressoria, alternate to opposite, ampulliform, 14-19 x 7-10 $\mu \mathrm{m}$. Mycelial setae scattered, straight, simple, obtuse at the tip, up to $440 \mu \mathrm{m}$ long. Perithecia scattered, up to $178 \mu \mathrm{m}$ in diam.; ascospores obovoidal, 4-septate, constricted at the septa, 43-50 x 17-19 $\mu \mathrm{m}$.

Materials examined: On leaves of Osyris arborea Wall. (Santalaceae), on the way to Mahabeleswar, Maharastra, Jan. 01, 2009, V.B. Hosagoudar and al TBGT 3688 (type). Meliola osyridicola Hansf. and M. osyridicola Hansf. var. indica Hosag. are known on the host genus Osyris from the Western Ghats of peninsular India (Hansford, 1961; Hosagoudar, 1996, 2008). However, Meliola mahamulkarii differs from both having $75 \%$ opposite appressoria.

\section{ACKNOWLEDGEMENTS}

We are grateful to Dr. A. Subramoniam, Director, TBGRI,

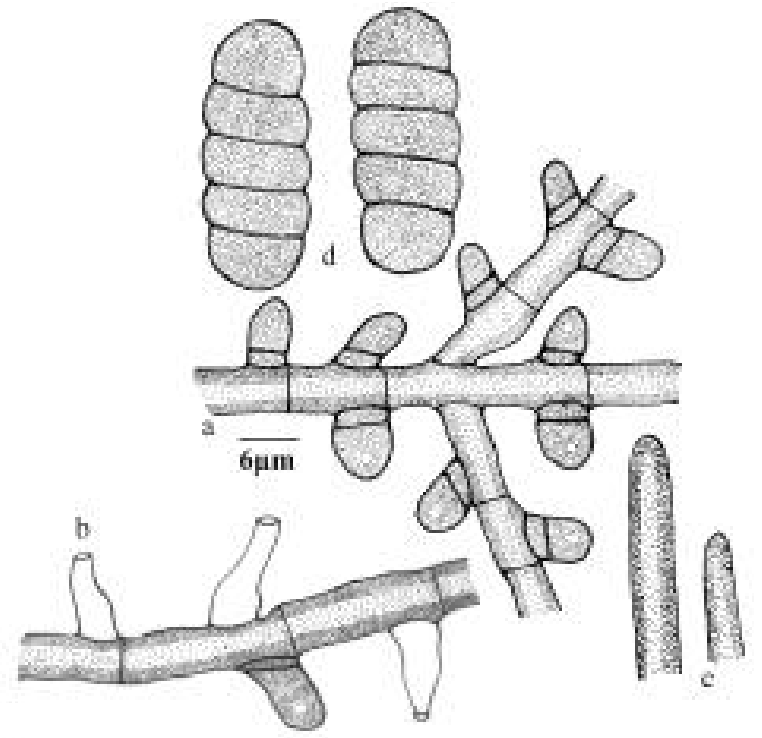

Fig. 2. Meliola mahamulkarii sp. nov. a. Appressoriate mycelium, b. phialide. c. Apical portion of the mycelial setae, d. Ascospores.

Palode for the facilities to the Dept. of Environment and Forests, New Delhi for the financial assistance. It is our privilege to acknowledge Profs. V.S. Khandekar, S.H. Mamulkar, D.A. Kadam, A.B. Pawar, D.N. Jadhav, B.A. Kore, Y.C. Institute, Satara for their help and inequitable hospitality during our collection trip. Mr. Girish Badave, is greatly acknowledged for his help in the identification of host plants.

\section{REFERENCES}

Deshpande, S., Sharma, B.D. and Nayar, M.P. (1993). Flora of Mahabaleshwar and adjoinings, Maharashtra. Vol. I. Botanical Survey of India, pp. 431.

Hansford, C.G. (1961). The Meliolineae. A Monograph. Sydowia. Beih. 2: 1-806.

Hosagoudar, V. B. (1996). Meliolales of India. Botanical Survey of India, Calcutta, pp. 363.

Hosagoudar, V. B. (2006). Studies on foliicolous fungi-XXV. New species and new records. Zoos. Print J., 21:2335-2338.

Hosagoudar, V. B. (2002). Studies on foliicolous fungi - X. Five new species and a new record. Ibid., 17: 943-948.

Hosagoudar, V. B. (2005). Studies on foliicolous fungi - XIX. Indian Phytopathol., 58: 94-204.

Hosagoudar, V. B. (2008). Meliolales of India, Vol.-II. Botanical Survey of India, pp. 390.

Hosagoudar, V. B. and Goos, R. D. (1996). Some foliicolous fungi from southern India. Mycotaxon., 59: 149-166.

Kamat, M. N., Patwardhan, P.G., Rao, V. G. and Sathe, A.V. (1971). Fungi of Maharashtra. Mahathma Phule KrishiVidyapeeth, Rahuri, Maharashtra State Bull. 1, pp. 124.

Patil, M.S. and Thite, A.N. (1980-81). Investigation of fungi of Mahabaleshwar. J. Shivaji Univ. (Sci.)., 20: 61-67.

Srinivasulu, B.V. (1974). The genus Meliola from Maharashtra. Nova Hedwigia, Beih., 47: 421-437.

Sydow, H. (1930). Fungi Venezuelani. Ann. Mycol., 28, 29224. 
Sydow, H. (1938). Novae fungorum species-XXVI. Ibid., 36: 156-253.

Sydow, H. and Sydow, P. (1915). Novae fungorum speciesXII. Ibid. 35-43.

Theissen, F. (1913). Dei Gattung Asterina. Bibliotheca Mycologica., 10:1-130.
Ursekar, M. S. (1977). Soil fungi of Mahabaleshwar. J. Univ. Poona Univ. Sci. Techn., 50: 119-126.

Yamamoto. W. (1956). The Formosan species of the Microthyriaceae-I. Sci. Rep. Hyogo Univ. Agric., 2: Ser. 2: 33-36. 